\title{
Business Model Transformation: Complexity and Systematic Transition to a Digital Platform
}

\author{
Kovalenko B.B. \\ University of the Inter-Parliamentary Assembly of the \\ Eurasian Economic Union, \\ St. Petersburg, Russia, \\ kovalenkoboris2015@gmail.com
}

\author{
Kovalenko E.G. \\ "ComplexSnab" Co Ltd., \\ St. Petersburg, Russia, \\ ksp.spb78@gmail.com
}

\begin{abstract}
Digital technologies are now becoming a key factor in maintaining the competitiveness of business organizations in the long term. The business models of companies functioning in the 20th century, which are a linear model, that is, a sequential value chain from producer to consumer, are no longer a criterion for market success. A new business model for organizations has emerged - the digital platform model. Organizations are using the digital platform business model to enable companies to explode and dominate the market. Studying the features of the functioning of digital platforms is important not only for startups, but also for companies with a stable market history and planning to increase their competitiveness through the use of digital business models. The issues related to the functioning of digital platforms, their impact on the activities of business organizations, and the difference from linear business models are considered. The result of the study was the identification of directions for the transformation of organizations and the necessary competencies for the transition from a linear business model to a digital platform model.
\end{abstract}

Keywords-business model transformation, digital platform, organizational changes

\section{INTRODUCTION}

Until recently, companies that had a history in the market and a stable, mature business sought to optimize a proven business model in the direction of adapting to external environmental conditions [1-3].

At the same time, information technologies (cloud, mobile, social networks, artificial intelligence, etc.) exert an increasingly strong influence on traditional methods of entrepreneurial activity.

Many leaders ponder the question: will companies in the conditions of digitalization be able to remain competitive in the long run if they adhere to familiar business models.

As the experience of a large number of European, North American, Asian companies in the context of digitalization shows, companies are forced not only to adjust the current business model, but to completely transform it and move to digital business models [4].
For organizations and leaders, the problem arises of matching the current business model of the company with market trends. An analysis of the performance of companies using digital business models shows that one of the most effective digital business models is the platform model [5].

This business model allows companies to achieve high financial performance and form a huge customer base, providing a very high customer service. Therefore, companies from different sectors of the economy are trying to move to this business model.

Currently, the issue of the mechanism of the transition of companies from the traditional business model (manufacturer, supplier, etc.) to the digital platform model and determining the direction of organizational changes necessary for the success of such a transformation is not sufficiently developed.

The authors tested the hypothesis that the platform's business model is very attractive, as it allows companies to move to accelerated development and increase competitiveness. However, the operation of the company on the principles of the platform requires other organizational skills and competencies than those that led to success in an industrial economy.

The authors investigated issues related to the types of platforms, their functions, working mechanisms, the impact on the market and financial performance of companies operating according to this business model.

The experience of the companies operating on the principle of the platform is analyzed: Apple, Facebook, Uber, Amazon, Wildberries, Beru, Sberbank, etc.

A comparative analysis of the linear business model and the platform model is carried out. The directions of transformation of the organization's activities for the transition from a linear business model to a platform model are proposed.

\section{RESEARCH METHODS}

In the process of research, methods of system analysis, company economics, management theory, and marketing were applied $[6,7]$. 
In recent years, work has been actively carried out and research has been conductedona strategy for creating and using business models by companies. The approach proposed by A. Osterwalder and I. Pinier [8], and considering the business model as a structure for creating and communicating to the consumer a value proposition and the formation of cost and income flows, became widespread in Russia.

This approach is very popular in the practice of entrepreneurship, based on the traditional principles of the economic activity of the company - the production of goods/services and their consistent implementation from producer to consumer.

At the same time, under the conditions of digital shifts, new types of business models have arisen, in particular, models of digital platforms, the functioning of which cannot be explained, following the postulates of the traditional theory of the company. In this regard, the provisions of the theory of bilateral markets were used to analyze the activities of digital platforms.

\section{FINDINGS}

\section{A. Business model of the digital platform - features of functioning}

\section{1) Types of platforms}

The platform's business model is a digital infrastructure that allows several groups of users to interact. They play the role of intermediaries between users: buyers and suppliers, manufacturers, partners, advertisers. According to studies, the following types of platforms are distinguished [9]:

- advertising platforms (Google, Facebook). These platforms organize the fulfillment of customer searches or their interactions with each other and sell companies the opportunity to advertise goods and services to customers of these platforms;

- cloud platforms - (AWS, Salesforce) are the owners of hardware and software and provide them to companies that do business on the Internet for rent;

- industrial platforms (GE, Siemens) transform existing production processes based on Internet technologies into services and provide them to customers;

- product platforms (Rollls Royce, Spotify) operate on the basis of other platforms, converting products into services;

- lean platforms (Uber, Airbnb) carry out activities based on the maximum cost reduction.

According to the approach proposed by A. Moazed and N. Johnson [10] the platforms are divided into the following types:

- Value exchange platforms in the following markets: services, goods, payment services, investment services, social networks, platforms for communication, social gaming platforms.

- Platforms for creativity: content platforms, application development platforms

The following platform business models are distinguished [11]: ecosystem, crowdsourcing, communities, digital market, data orchestrator.

\section{2) The mechanism of operation of digital platforms}

The digital platform is a technical interface that allows various user groups to interact with each other [9, 12].

At the same time, it is important that this interaction is just comfortable for users, which allows you to connect a large number of them to the platform.

Compared with companies in traditional industries, platforms get a huge advantage associated with access to user data for subsequent use of this data for commercial and other purposes (Google, Facebook, Apple, etc.)

A feature of the platforms is their reliance on network effects. An increase in the number of users of the platform increases its value to other users. The presence of network effects allows the platforms to develop at a very high rate in a short time and multiply the number of clients. Table I shows the number of clients for the largest digital platforms.

TABLE I. THE NUMBER OF CUSTOMERS OF THE LARGEST WORLD PLATFORMS

\begin{tabular}{|c|c|}
\hline Platform name & Number of customers, mln. \\
\hline Facebook & 1590 \\
\hline YouTube & 1000 \\
\hline WhatsApp & 1000 \\
\hline WeChat & 650 \\
\hline Alibaba & 407 \\
\hline Instagram & 400 \\
\hline Twitter & 320 \\
\hline
\end{tabular}

The platform's business model is subject to the theory of functioning of bilateral markets. In such markets, one of its parties benefits from the presence of those on the other side. Between such groups external effects (externalities) occur.

In the event that the presence of the other is profitable on one side of the market, the created platforms can use the "swing" principle to monetize their activities. That is, they charge a large fee for connecting to the platform from users on one side and a minimal fee on the other, which allows you to attract a large number of customers. Such a tool is crosssubsidization.

In the process of the platform's activities, they create a digital ecosystem, which includes partners providing additional products / services in order to provide an integrated multiproduct offer for the client. Sometimes such products compete with each other, but the platform does this in order to provide an excellent client and increase the number of clients connected to it.

The main functions of the platforms are as follows [10]:

- Attracting an audience.

- Coordination.

- Providing tools and services.

- Definition of rules and standards 
As we noted earlier, the platform is an example of an organization operating in the bilateral market. In the process, the platform interacts between both sides of the market (customers and suppliers).

As we noted earlier, the platform is an example of an organization operating in the bilateral market. The platform interacts between both sides of the market (customers and suppliers)

In the process of the platform's activity, competition between suppliers intensifies, prices decrease, which has a positive effect on attracting customers to the platform.

Platforms in some cases regulate the prices of suppliers up or down depending on the situation.

The quality control of the platform is also carried out:

- a ban on unethical behavior;

- restriction on connecting partners and customers to the platform that do not meet certain criteria;

- depositing customer funds and transferring them to the supplier only after the customer has received the order, etc.

A common practice is to provide information to customers about the reliability of suppliers through their rating.

Research results show that the platform model is superior to other digital business models in terms of marketing, innovation and financial performance. Table II provides a comparative analysis of the performance of digital business models.

TABLE II. RESUlts OF A COMPARATIVE ANALYSIS OF THE PERFORMANCE OF THE DIGITAL BUSINESS MODELS

\begin{tabular}{|l|c|c|c|c|}
\hline \multicolumn{1}{|c|}{$\begin{array}{c}\text { Digital } \\
\text { Business } \\
\text { model }\end{array}$} & $\begin{array}{c}\text { Consumer } \\
\text { experience }\end{array}$ & $\begin{array}{c}\text { Implementation } \\
\text { period of } \\
\text { innovation }\end{array}$ & $\begin{array}{c}\text { Profit- } \\
\text { ability } \\
\text { growth }\end{array}$ & $\begin{array}{c}\text { Net } \\
\text { profit } \\
\text { margin }\end{array}$ \\
\hline The supplier & $65 \%$ & $50 \%$ & $33 \%$ & $34 \%$ \\
\hline Omnichannel & $80 \%$ & $75 \%$ & $40 \%$ & $40 \%$ \\
\hline $\begin{array}{l}\text { Modular } \\
\text { manufacturer }\end{array}$ & $70 \%$ & $63 \%$ & $43 \%$ & $46 \%$ \\
\hline Platform & $80 \%$ & $78 \%$ & $51 \%$ & $50 \%$ \\
\hline
\end{tabular}

3) Linear business model and platform model - comparative characteristics

The experience of Western and Russian companies, large market players, whose business model is organized according to the principle of a digital platform: Apple, Facebook, Uber, Amazon, Wildberries, Beru, Sberbank etc. was studied. A comparative analysis of two business models: linear and digital platforms was carried out. Table III presents the analysis results.

As follows from the analysis, the platform is an effective business model that can allow companies in the face of digital pressure not only to remain competitive, but also to occupy a dominant market position.

However, it should be borne in mind that the business model of the platform operates on other principles than the traditional business model of the company. At the same time, old-timers do not have experience with the new model.
TABLE III. COMPARISON RESULTS OF BUSINESS MODELS: LINEAR AND PLATFORM

\begin{tabular}{|l|l|}
\hline \multicolumn{1}{|c|}{ Linear Model } & \multicolumn{1}{c|}{ Platform } \\
\hline $\begin{array}{l}\text { Creating value in the form of goods } \\
\text { / services }\end{array}$ & $\begin{array}{l}\text { Increasing value through incentive } \\
\text { operations }\end{array}$ \\
\hline $\begin{array}{l}\text { Realization of value along the value } \\
\text { chain }\end{array}$ & $\begin{array}{l}\text { Implementing the exchange of value } \\
\text { between multiple user groups }\end{array}$ \\
\hline $\begin{array}{l}\text { Business expansion and growth } \\
\text { through the acquisition of physical } \\
\text { assets, marketing }\end{array}$ & $\begin{array}{l}\text { Business growth through network } \\
\text { effects }\end{array}$ \\
\hline $\begin{array}{l}\text { Business performance is achieved } \\
\text { through economies of scale and } \\
\text { streamlined supply chains }\end{array}$ & $\begin{array}{l}\text { Efficiency is achieved through the } \\
\text { optimal formation of the ecosystem, } \\
\text { networks of users, suppliers, } \\
\text { partners, increased transactions }\end{array}$ \\
\hline $\begin{array}{l}\text { Focus on one-time transactions, low } \\
\text { product customization }\end{array}$ & $\begin{array}{l}\text { Recurring transactions, high } \\
\text { customization of the offer }\end{array}$ \\
\hline Discrete revenue streams & Continuous revenue streams \\
\hline
\end{tabular}

Source: Own results

\section{B. Transition to the platform's business model: areas of transformation}

In the event that the company encounters difficulties in operating the current business model, the following strategic decisions are possible that are made by management:

- adjustment of the current (traditional) business model;

- transition to a new (digital) business model;

- leaving the market and liquidation of the company.

Studying the experience of companies that have made the transition to a digital business model shows that transformation is associated with two difficulties.

First, the difficulty of abandoning established business processes within the framework of the existing model, which bring a guaranteed stream of income.

Secondly, the uncertainty in entering a new business model, which undermines the existing structures, processes and systems in the company and can lead to weakening market positions.

To move to the platform's business model from a traditional manufacturer / supplier model of a product or service requires solving problems in two directions.

The first direction is related to the refusal of the company to provide customers with single transactions (a single product / service) and the transition to a model with a comprehensive assumption of value and a regular income stream.

The second direction involves solving the problems of moving from an individualized offer of products / services to a mass customized offer.

A study conducted by the authors shows that solving the problem of transition to a digital business model in two of the above areas at once is a complex problem and requires phased implementation.

In our opinion, it is necessary to implement the following approach:

- Definition of the current business model (current state).

- The planned business model is the platform (target state). 
- Transition strategy (goals, objectives, measures, directions of changes).

The transition from a weaving business model to a platform model involving organizational restructuring of the company.

What are the main directions of the company's activities that need to be transformed in the transition to the platform model? What organizational competencies need to be developed?

The results of the authors' analysis of market practices, as well as consideration of the theoretical aspects of bilateral markets.

Based on the principles of comprehensiveness and systems approach, the authors proposed directions for transforming the activities of companies in the transition from a linear business model to a platform model. These directions include the following:

- customer service (interaction with customers);

- operational processes;

- organizational structure, culture;

- mission, strategy, culture.

The specific contents of the directions of transformation are presented in Table IV.

TABLE IV. DiRECTIONS OF TRANSFORMATION OF LINEAR BUSINESS MODEL TO A PLATFORM BUSINESS MODEL

\begin{tabular}{|c|c|}
\hline $\begin{array}{c}\text { Directions of } \\
\text { transformation }\end{array}$ & The content of the transformation processes \\
\hline Customer service & $\begin{array}{l}\text { The client is the basis of all the company's business } \\
\text { processes } \\
\text { The formation of a value proposition in accordance } \\
\text { with the life cycle of the client } \\
\text { Organization of omnichannel } \\
\text { Providing customers with comprehensive products / } \\
\text { services } \\
\text { Emphasis on creating a base of regular customers }\end{array}$ \\
\hline $\begin{array}{l}\text { Operational } \\
\text { processes }\end{array}$ & $\begin{array}{l}\text { Forming an affiliate network and creating platform } \\
\text { software for connecting clients and partners } \\
\text { Creation of an internal platform to provide integrated } \\
\text { customer service processes } \\
\text { Creating API (application programming interface) }\end{array}$ \\
\hline $\begin{array}{l}\text { Organizational } \\
\text { structure, culture }\end{array}$ & $\begin{array}{l}\text { Horizontal organizational structures } \\
\text { Flexible design teams } \\
\text { A framework that supports continuous business } \\
\text { process innovation } \\
\text { Employee motivation based on involvement and } \\
\text { leadership at every workplace }\end{array}$ \\
\hline $\begin{array}{l}\text { Mission, Strategy, } \\
\text { Politics }\end{array}$ & $\begin{array}{l}\text { The formation of the brand as the best, providing } \\
\text { comprehensive solutions to customers in the relevant } \\
\text { field (health, daily needs, etc.) } \\
\text { Strategic decisions are based on the analysis of big } \\
\text { customer data } \\
\text { Development of a strategy for the functioning of the } \\
\text { platform in order to obtain network effects } \\
\text { Platform policy related to the formation of a client } \\
\text { base, the protection of personal data of participants } \\
\text { Pricing policy that assumes a steady stream of income }\end{array}$ \\
\hline
\end{tabular}

\section{DISCUSSION}

The use of new digital technologies allows you to modify business processes or even abandon some of them, which leads to the need to transform the existing business model.
An analysis of the performance of companies using digital business models shows that one of the most effective digital business models is the platform model.

The results confirm the hypothesis that the functioning of the platforms is based on the theory of bilateral markets and differs from the traditional theory of the company. The hypothesis is also confirmed that the specifics of the platform's activities require other organizational competencies aimed at creating and developing network effects.

The results obtained are consistent with research in this area $[4,5,11,13-15]$. The authors have proposed integrated and systems approach to the transformation process of a linear business model to a platform. This approach involves the following areas of transformation of the company's business processes:

- customer service (interaction with customers);

- operational processes;

- organizational structure, culture;

- mission, strategy, culture.

According to the authors, the research prospects are associated with the development of specific procedures and tools that companies and organizations can use in their practical activities to make the transition to the platform's business model.

\section{CONCLUSION}

What is the reason for the market success of companies such as Amazon, Apple, YouTube, Alibaba, Android, Twitter, etc., which have shown explosive growth and attracted such a number of customers that are comparable with the population of the largest states of the world?

The answer lies in the fact that they carry out their activities on the basis of the platform's business model, which emerged in the digital age and allows such unicorn companies to gain a monopoly position in the markets.

Our gratitude to the following researchers $[9,10,12]$ who prepared and published materials revealing the features of the platforms. Their work presents a wealth of practical material relating to the activities of well-known companies using this business model. Thanks to these materials and studies, the authors came up with the idea to study the issue regarding the platform's mechanism of activity and formulate directions for the transformation of companies from a linear business model to a platform model.

\section{References}

[1] N. Bostrom, "Superintelligence. Paths, Dangers, Strategies", 1 $1^{\text {st }}$ d., Moscow, Mann, Ivanov and Ferber, 2016.

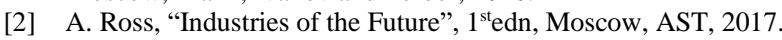

[3] K. Schwab and N. Davis, "Technologies of the Fourth Industrial Revolution", 1 1 ed., Moscow, Eksmo, 2018.

[4] MITSloan Management Review, "Digitalization: Practical Guidelines for

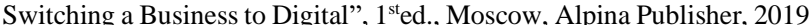

[5] P. Weill and S. Woerner, "Digital Transformation of Business: Changing the Business Model for the Organization of a New Generation", $1^{\text {st }}$ ed. Moscow, Alpina Publisher, 2019.

[6] R. Coase, "The Nature of the Firm. Origins, Evolution, and

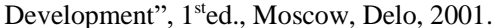


[7] P. Samuelson and W. Nordhaus, "Economics", 18th edn. Moscow, Publishing House Williams, 2015.

[8] A. Osterwalder and I. Pigne, "Building Business Models. Handbook of

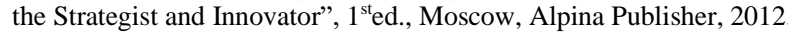

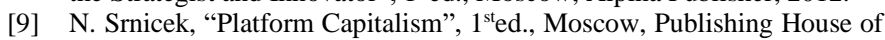
the Higher School of Economics, 2019.

[10] A. Moazed and N. Johnson, "Platform: The Practical Application of a

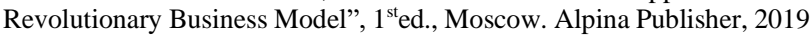

[11] J. Loucks, J. Macaulay, A. Noronha and M. Wade, "Digital Vortex. How Today's Market Leaders Can Beat Disruptive Competitors at Their Own

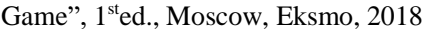

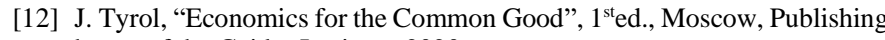
house of the Gaidar Institute, 2020.

[13] McKinsey Global Institute, Digital Globalization: Executive Summary, 2016. Retrieved from https://www.mckinsey.com/businessfunctions/mckinsey-digital/our-insights/digital-globalization-the-newera-of-global-flows.

[14] L. Gansky, "Mesh-model. Why the Future of Business is in Sharing

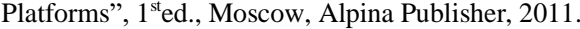

[15] C. Linz, G. Muller-Stewens and A. Zimmermann, "A Radical Change in Business Model: Adaptation and Survival in a Competitive

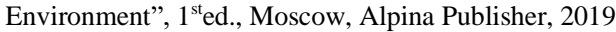

